\title{
PENGARUH METODE PEMBELAJARAN DAN GAYA BELAJAR TERHADAP HASIL BELAJAR PENDIDIKAN KEWARGANEGARAAN SISWA KELAS $X$ SMK NEGERI 1 BALIGE
}

\author{
Novalina Evodya Tumanggor ${ }^{1}$, Abdul Muin Sibuea ${ }^{2}$ \\ SMK Negeri 1 Balige ${ }^{1}$, Pascasarjana Universitas Negeri Medan ${ }^{2}$ \\ novalina_evodya@yahoo.com ${ }^{l}$
}

\begin{abstract}
Abstrak: Penelitian ini bertujuan untuk mengetahui: (1) hasil belajar Pendidikan Kewarganegaraan siswa yang diajar dengan metode pembelajaran simulasi lebih tinggi daripada hasil belajar Pendidikan Kewarganegaraan siswa yang diajar dengan metode pembelajaran ekspositori, (2) hasil belajar pendidikan kewarganegaraan siswa yang memiliki gaya belajar kinestetik lebih tinggi daripada siswa yang memiliki gaya belajar auditori, dan (3) interaksi antara metode pembelajaran dan gaya belajar dalam mempengaruhi hasil belajar Pendidikan Kewarganegaraan. Metode penelitian ini adalah kuasi eksperimen dengan desain faktorial $2 \times 2$. Teknik analisis yang digunakan adalah analisis varian dua jalur (ANAVA $2 x \quad 2)$ dengan taraf $\alpha=0,05$, dan diuji dengan menggunakan uji Tukey. Hasil penelitian menunjukkan bahwa: (1) Metode pembelajaran simulasi memberikan hasil belajar Pendidikan Kewarganegaraan siswa yang lebih baik bila dibandingkan dengan metode pembelajaran ekspositori; (2) Kelompok siswa yang memiliki gaya belajar kinestetik memperoleh skor hasil belajar Pendidikan Kewarganegaraan yang lebih baik bila dibandingkan dengan kelompok siswa yang memiliki gaya belajar auditori; (3) Terdapat interaksi antara metode pembelajaran dengan gaya belajar dalam mempengaruhi hasil belajar Pendidikan Kewarganegaraan.
\end{abstract}

Kata Kunci: metode pembelajaran, gaya belajar, hasil belajar pendidikan kewarganegaraan

Abstract: This study aims to determine: (1) the learning outcomes Citizenship Education students who are taught by the teaching methods of simulation is higher than the result of learning Citizenship Education students who are taught by the method of expository, (2) the learning outcomes of civic education of students who have a kinesthetic learning style higher than students who have auditory learning styles, and (3) the interaction between teaching methods and learning styles in influencing learning outcomes Citizenship Education. This research method is a quasi-experimental design with 2 $x 2$ factorial analysis technique used is the analysis of variance of two lanes (ANOVA $2 \times 2$ ) with a level of $\alpha=0.05$, and tested using Tukey test. The results showed that: (1) The learning method simulation results Citizenship Education students learn better when compared with expository teaching methods; (2) The group of students who have obtained a score of kinesthetic learning style Citizenship Education learning outcomes are better when compared with a group of students who have auditory learning style; (3) There is an interaction between the learning method with learning styles in influencing learning outcomes Citizenship Education.

Keywords: teaching methods, learning styles, learning outcomes civic education

\section{PENDAHULUAN}

Pembelajaran

Kewarganegaraan sebenamya mempunai peran yang sangat penting. Mata diklat Pendidikan Kewarganegaraan diharapkan akan mampu membentuk siswa yang memiliki mental yang kuat, sehingga dapat mengatasi permasalahan yang akan dihadapi. Dengan demikian yang perlu diperhatikan dalam memotivasi siswa untuk mencapai hasil belajar pendidikan kewarganegaraan yang lebih baik bahwa praktik pembelajaran pendidikan kewarganegaraan membutuhkan keteladanan dan suasana yang baik di sekolah, keluarga, dan masyarakat

Sehubungan dengan yang dikemukakan di atas, secara umum guru yang mengajarkan mata diklat Pendidikan Kewarganegaraan masih menggunakan metode pembelajaran ekspositori dalam menerapkan pembelajarannya. Salah satunya dengan menggunakan buku teks sebagai sumber belajar. Dalam buku teks terdapat begitu banyak materi pembelajaran. Jika semua materi 
pembelajaran ini disampaikan kepada siswa, tentu sangat sulit bagi mereka untuk menguasainya. Kesulitan itu berkenaan dengan usaha memahami ide-ide pokok dari materi yang diajarkan termasuk untuk mengingat kembali isi materi pembelajaran yang pernah dipelajari. Pembelajaran yang dikemukakan di atas kurang optimal dan tidak terstruktur dengan baik dalam memori siswa, sehingga berakibat pada rendahnya hasil belajar Pendidikan Kewarganegaraan.

Kenyataan seperti yang dikemukakan di atas tampak dalam pembelajaran Pendidikan Kewarganegaraan di SMK Negeri 1 Balige. Berdasarkan hasil pengamatan, ternyata hasil belajar siswa dalam mata diklat ini masih dikategorikan rendah. Hal ini dapat dilihat dari data siswa di SMK Negeri 1 Balige masih banyak yang memperoleh nilai rendah mata diklat Pendidikan Kewarganegaraan, yang disebabkan oleh berbagai faktor, baik faktor internal maupun faktor eksternal yang mempengaruhi hasil belajar Pendidikan Kewarganegaraan. Karena itu dirasa perlu dilaksanakan metode pembelajaran tertentu agar lebih meningkatkan hasil belajar Pendidikan Kewarganegaraan. Salah satu cara yang dapat dilakukan oleh guru dalam usaha meningkatkan hasil belajar Pendidikan Kewarganegaraan yang tinggi adalah dengan memilih metode pembelajaran yaitu metode pembelajaran simulasi.

Belajar adalah suatu aktivitas mental/ psikis, yang berlangsung dalam interaksi aktif dengan lingkungan, yang menghasilkan sejumlah perubahan dalam pengetahuan, pemahaman, keterampilan dan nilai sikap. Perubahan itu bersifat konstan dan berbekas (Winkel, 2009). Gagne (1979) menyatakan belajar adalah suatu proses yang kompleks dan belajar mempunyai delapan tipe. Kedelapan tipe itu bertingkat, ada hierarki dalm masing-masing tipe. Setiap tipe belajar merupakan prasyarat bagi tipe belajar di atasnya. Kedelapan tipe itu adalah: (1) belajar isyarat (singal learning), bentuk belajar seperti ini biasanya bersifat tidak disadari, dalam arti respons diberikan secara tidak sadar, (2) belajar stimulus respons (stimulus respons learning), di mana setiap respons dapat diperkuat dengan reinforcement, (3) belajar rangkaian (chaining), yaitu semacam rangkaian antara stimulus/ respons yang bersifat segera. Hal ini terjadi pada rangkaian motorik, (4) asosiasi verbal (verbal association), tipe ini mampu mengaitkan suatu yang bersifat verbalisme kepada sesuatu yang sudah dimilikinya, (5) belajar diskriminasi (discrimination learning), tipe belajar ini adalah pembedaan terhadap berbagai rangkaian, seperti membedakan bentuk wajah, (6) belajar konsep (concept learning), konsep merupakan simbol berpikir, ini diperoleh dari memuat tafsiran terhadap fakta atau realita, dan hubungan antar fakta, (7) belajar aturan (rule learning), seseorang dipandang telah memiliki berbagai konsep yang dapat digunakan untuk mengemukakan berbagai formula, hukum atau dalil, dan (8) belajar pemecahan masalah (problem solving), dapat dilakukan oleh seseorang apabila dalam dirinya sudah mampu mengaplikasikan berbagai aturan yang relevan dengan masalah yang dihadapinya.

Menurut Gagne (1979) hasil belajar merupakan kemampuan yang disebabkan oleh: (1) stimulus yang berasal dari lingkungan dan (2) proses kognisi yang dilakukan oleh siswa. Belajar terjadi bila ada hasil yang dapat diperlihatkan berupa tingkah laku. Tingkah laku itu meliputi pengetahuan, keterampilan dan keahlian. Pengetahuan merujuk kepada informasi yang tersirat dalam pikiran, sedangkan keterampilan adalah suatu tindakan atau tingkah laku yang mampu diperlihatkan seseorang sebagai tanda bahwa orang tersebut mempunyai sikap. Selanjutnya sikap adalah kemampuan menerima atau menolak objek berdasarkan penilaian terhadap objek tersebut. Peubahan tingkah laku diperoleh dengan adanya usaha belajar, berarti perubahan tingkah laku dapat disebut sebagai hasil belajar yang diperoleh dari usaha belajar untuk dapat digunakan dan dimanfaatkan dalam aktivitas sehari-hari. Faktor yang mempengaruhi hasil belajar tidak terlepas dari faktor intern dan faktor ekstern. Faktor intern terdiri atas faktor-faktor jasmaniah, psikologi, dan kelelahan. Faktor ekstern juga mempengaruhi hasil belajar siswa yang terdiri dari lingkungan, faktor sekolah, dan faktor masyarakat (Slameto, 2010).

Hasil belajar adalah objek dari evaluasi produk. Hasil belajar akan nampak dalam prestasi belajar atau dalam produk yang dihasilkan, yaitu kemampuan siswa. Melalui evaluasi produk, dapat diselidiki apakah dan seberapa jauh suatu tujuan instruksional telah tercapai. Evaluasi produk ini dapat digunakan untuk mendapatkan informasi tentang masingmasing siswa, samapai sejauh mana mereka telah mencapai tujuan instruksional atau tentang suatu kelompok, samapi seberapa jauh kelompok itu mencapai aneka tujuan pembelajaran (Winkel, 
2009). Selanjutnya Snelbecker

(1984) mengatakan bahwa ciri-ciri tingkah laku yang diperoleh dari hasil belajar adalah (a) terbentuknya tingkah laku baru berupa kemampuan aktual maupun potensial, (b) kemampuan itu berlaku dalam waktu yang relatif lama, dan (c) kemampuan baru itu diperoleh melalui usaha.

Howard dalam Slameto (2003) mendefinisikan pembelajaran sebagai aktivitas untuk mencoba membantu, membimbing seseorang untuk mendapatkan, mengubah atau mengembangkan skill, attitude, ideals (cita-cita), appreciations (penghargaan) dan knowledge (pengetahuan). Dalam pengertian ini guru harus berusaha membawa perubahan tingkah laku yang baik atau kecenderungan langsung untuk mengubah tingkah laku siswanya.

Reigeluth (1983) mengatakan bahwa: Instructional methods are the different ways to achieve different outcomes under different conditions. Yang artinya bahwa metode pembelajaran adalah suatu cara untuk mencapai hasil yang baik pada situasi yang berbeda. Dalam hal ini guru sebagai tenaga perancang pembelajaran (instructional designer) harus mampu memanipulasi situasi, atau keadaan, cara sehingga menjadi suatu suasana yang menarik.

Menurut De Cecco and Crow (1983) metode pembelajaran adalah kegiatan terencana dengan mempertimbangkan tujuan pembelajaran yang jelas, memudahkan menyusun materi pelajaran, proses kegiatan dan alat evaluasi. Hal ini berarti salah satu jalan yang ditempuh guru dalam usaha mencapai atau peningkatan hasil belajar yang tinggi perlu membenahi metode pembelajarannya.

Suparman (1993) mendefinikan metode pembelajaran adalah berbagai perpaduan dari 1) urutan kegiatan instruksional, 2) cara pengorganisasian materi pengajarn dan peserta belajar, 3) peralatan dan bahan, dan 4) waktu yang digunakan dalam proses instruksional. Sejalan dengan itu Seels and Richey (1994: 129) mengatakan bahwa metode pembelajaran adalah spesifikasi pemilihan dan pengurutan kegiatan dalam suatu pengajaran tertentu.

Menurut Rusman (2009: 297) metode simulasi pada dasarnya merupakan salah satu strategi pembelajaran yang bertujuan memberikan pengalaman belajar yang lebih konkret melalui penciptaan tiru-tiruan bentuk pengalaman yang mendekati suasana sebenarnya dan berlangsung dalam suasana yang tanpa resiko. Metode simulasi menampilkan materi pelajaran yang dikemas dalam bentuk simulasisimulasi pembelajaran dalam bentuk animasi yang menjelaskan konten secara menarik, hidup, dan memadukan unsur teks, gambar, audio, gerak, dan paduan warna yang serasi dan harmonis.

Joyce dan Weil (2007: 364) menjelaskan bahwa ada 4 (empat) peranan guru dalam metode simulasi yaitu; menjelaskan (explaining), mewasiti (refereeing), melatih (coaching), dan diskusi (discussing). Menurut Joyce dan Weil (2007) proses pembelajaran tidak hanya memiliki makna deskriptif dan kekinian, akan tetapi juga bermakna prospektif dan berorientasi masa depan. Setiap metode pembelajaran memiliki unsur-unsur seperti: (1) sintakmatik, (2) sistem sosial, (3) prinsip reaksi, (4) sistem pendukung, dan (5) dampak instruksional dan pengiring (penyerta).

Sanjaya (2007: 179) metode pembelajaran ekspositori adalah metode pembelajaran yang menekankan kepada proses penyampaian materi secara verbal dari seorang guru kepada sekelompok siswa dengan maksud agar siswa dapat menguasai materi pelajaran secara optimal. Beberapa langkah dalam penerapan pembelajaran ekspositori: (1) persiapan (preparation), yaitu berkaitan dengan mempersiapkan siswa untuk menerima pelajaran; (2) penyajian (presentation) berkaitan dengan penyampaian materi pelajaran sesuai dengan persiapan yang telah dilakukan; (3) menghubungkan (correlation) berkaitan dengan menghubungkan materi pelajaran dengan pengalaman siswa atau hal-hal lain yang memungkinkan siswa dapat menangkap keterkaitannya dalam struktur pengetahuan yang telah dimilikinya; (4) menyimpulkan (generalization) berkaitan dengan memahami inti (core) dari materi pelajaran yang telah disajikan; (5) mengaplikasikan (Aplication) berkaitan dengan langkah unjuk kemampuan siswa setelah mereka menyimak penjelasan guru".

Metode pembelajaran ekspositori merupakan bentuk pendekatan pembelajaran yang berorientasi kepada guru (teacher centered approach). Hal ini disebabkan bahwa dalam metode ini guru memegang peranan yang sangat dominan. Menurut Sanjaya (2007: 179) terdapat karakteristik metode ekspositori sebagai berikut: 1) metode ekspositori dilakukan dengan cara menyampaikan materi pelajaran secara verbal, artinya bertutur secara lisan merupakan alat utama dalam melakukan metode ini, oleh karena itu sering orang mengidentifikasikannya dengan 
ceramah, 2) biasanya materi pelajaran yang disampaikan adalah materi pelajaran yang sudah jadi, seperti data, fakta, konsep-konsep tertentu yang harus dihapal sehingga tidak menuntut siswa untuk berpikir ulang, 3) tujuan utama pembelajaran adalah penguasaan materi pelajaran itu sendiri, artinya setelah proses pembelajaran berakhir siswa diharapkan dapat memahaminya dengan benar dengan cara dapat mengungkapkan kembali materi yang telah diuraikan.

Miarso (2004: 530) menjelaskan bahwa garis besar proses belajar pada teori pemrosesan informasi (information processing learning) adalah sebagai berikut: 1) pembelajar menerima informasi mengenai prinsip atau dalil yang dijelaskan dengan memberi contoh, 2) terjadinya pemahaman pada diri pembelajar atas prinsip atau dalil yang diberikan, 3) pembelajar menarik kesimpulan berdasarkan kepentingannya yang khusus dan 4) terbentuknya tindakan pada diri pembelajar yang merupakan hasil pengolahan prinsip/ dalil dalam situasi yang sebenarnya. Sedangkan penerapan metode ekspositori adalah sebagai berikut: a) informasi disajikan kepada pembelajar, b) diberikan tes penguasaan, serta penyajian ulang bilamana dipandang perlu, c) diberikan kesempatan penerapan dalam bentuk contoh dan soal, dengan jumlah tingkat kesulitan yang bertambah, d) diberikan kesempatan penerapan informasi baru dalam situasi dan masalah yang sebenarnya.

Metode pembelajaran ekspositori memiliki keunggulan dan kelemahan. Sanjaya (2007: 188) menyatakan " keunggulan metode pembelajaran ekspositori adalah (1) guru bisa mengontrol urutan dan keluasan materi pembelajaran, sehingga dapat diketahui sejauh mana siswa menguasai bahan pelajaran yang disampaikan, (2) dapat menyampaikan materi pelajaran cukup luas dengan menggunakan waktu belajar yang terbatas, (3) siswa dapat mendengar melalui penuturan tentang suatu materi pelajaran juga sekaligus siswa bisa melihat atau mengobservasi; dan (4) bisa digunakan untuk jumlah siswa dalam ukuran kelas yang besar".

Sedangkan beberapa kelemahan metode pembelajaran ekspositori menurut Sanjaya (2007: 189) adalah: (1) pembelajaran ini hanya mungkin dapat dilakukan terhadap siswa yang memiliki kemampuan mendengar dan menyimak secara baik, (2) pembelajaran dengan ekspositori tidak mungkin dapat melayani perbedaan setiap individu, baik perbedaan kemampuan, perbedaan pengetahuan, minat, dan bakat, serta perbedaan gaya belajar, (3) karena metode lebih banyak diberikan melalui ceramah, maka akan sulit mengembangkan kemampuan siswa dalam hal kemampuan sosialisasi, hubungan interpersonal, serta kemampuan berpikir kritis, (4) keberhasilan pembelajaran ekspositori tergantung kepada apa yang dimiliki guru, seperti persiapan, pengetahuan rasa percaya diri, semangat, antusiasme, motivasi, dan berbagai kemampuan seperti kemampuan bertutur (berkomunikasi), dan kemampuan mengelola kelas, (5) oleh karena gaya komunikasi pembelajaran lebih banyak terjadi satu arah (one-way comunnication), maka kesempatan untuk mengontrol pemahaman siswa akan materi pelajaran sangat terbatas pada komunikasi satu arah bisa mengakibatkan pengetahuan yang dimiliki siswa akan terbatas pada apa yang diberikan guru".

Di dalam kelas biasanya terdiri atas bermacam-macam karakteristik membuat seorang guru kesusahan memilih metode pembelajaran yang efektif dan efesien. Dick \& Carey (2001) menyarankan agar seorang guru perlu mempertimbangkan karakteristik siswa yang akan dibelajarkan. Gaya belajar adalah salah satu karateristik yang dimiliki siswa. Gaya belajar adalah cara yang lebih kita sukai dan membuat kita nyaman dalam dalam melakukan kegiatan berpikir, memproses dan mengerti suatu informasi. Gaya belajar merupakan karakteristik penting dari berbagai ciri yang mempengaruhi cara siswa belajar. Menurut De Porter dan Henarcki (2003) bahwa gaya belajar seseorang adalah kombinasi dari bagaimana ia menyerap dan kemudian mengatur serta mengolah informasi.

Gunawan (2004: 139) menyatakan bahwa gaya belajar adalah cara yang lebih disukai dalam melakukan kegiatan berpikir, memproses dan mengerti suatu informasi. Misalnya jika siswa ingin mempelajari mengenai tanaman, apakah siswa lebih suka menonton video soal tanaman, mendengarkan ceramah, membaca buku atau siswa bekerja langsung di perkebunan atau mengunjungi kebun raya.

Nasution (2005: 94) mendefinisikan gaya belajar sebagai suatu cara yang konsisten yang dilakukan oleh seorang siswa dalam menangkap stimulus atau informasi, cara mengingat, berpikir, dan memecahkan masalah. Setiap orang memiliki gaya belajar yang berbeda. Selain berbeda dalam tingkat kecakapan, memecahkan masalah, taraf kecerdasan, atau 
kemampuan berpikirf kreatif, juga berbeda dalam memperoleh, menyimpan dan mengolah informasi.

Visual adalah belajar dengan cara melihat, auditorial belajar dengan cara mendengar sedangkan kinestetik adalah belajar dengan cara bergerak, bekerja dan menyentuh. Ketiganya adalah merupakan modalitas belajar (De Porter dan Hernacki, 2003). Pendekatan berdasarkan preferensi sensori mencakup gaya belajar visual, auditorial dan kinestetik. Dan dalam penelitian ini gaya belajar yang dimaksud digolongkan menjadi dua kategori, yakni gaya belajar kinestetik dan gaya belajar auditori.

Menurut Gunawan (2004: menyebutkan bahwa siswa yang memiliki gaya belajar kinestetik sangat peka terhadap perasaan atau emosi dan pada sensasi sentuhan dan gerakan. Bila diminta untuk menuliskan suatu kata, siswa yang memiliki gaya belajar kinestetik akan "merasakan" dulu kata tersebut baru setelah itu, menuliskan kata tersebut. Siswa yang memiliki gaya belajar kinestetik akan belajar maksimal dalam suatu kondisi dimana banyak keterlibatan fisik dan gerakan. Ciri-ciri fisiologi siswa yang memiliki gaya belajar kinestetik adalah: (a) gerakan bola mata ke arah bawah, (b) pernafasan perut dan dalam, (c) suara cenderung berat, (d) menggunakan gerakan/ bahasa tubuh, (e) mengakses informasi sambil melihat ke bawah. Sedangkan ciri bahasa yang sering digunakan siswa yang memiliki gaya belajar kinestetik adalah: (1) ini rasanya kurang pas, (2) saya ingin anda merasakan hal ini, (3) ini rasanya masih kurang jelas.

De Porter \& Hernacki (2003: 114) menyatakan bahwa siswa yang memiliki gaya belajar kinestetik lebih baik aktivitas bergerak dan interaksi kelompok. Lebih lanjut De Porter \& Hernacki menunjukkan ciri-ciri siswa yang memiliki gaya belajar kinestetik yakni: (1) berbicara dengan perlahan, (2) menanggapi perhatian fisik, (3) menyentuh orang untuk mendapatkan perhatian, (4) berdiri dekat ketika berbicara dengan orang, (5) selalu berorientasi pada fisik dan banyak bergerak, (6) mempunyai perkembangan awal otot-otot besar, (7) belajar melalui memanipulasi dan praktik, (8) menghafal dengan cara berjalan dan melihat, (9) menggunakan jari sebagai penunjuk ketika membaca, (10) banyak menggunakan syarat tubuh, (11) tidak dapat duduk diam untuk waktu lama.

Menurut De Porter et al (2001: 85) bahwa siswa yang memiliki gaya belajar kinestetik adalah siswa yang memiliki modalitas mengakses segala jenis gerak dan emosi yang diciptakan maupun yang diingat. Gerakan koordinasi, irama, tanggapan emosional dan kebanyakan kegiatan fisik yang menonjol. Siswa yang memiliki gaya belajar kinestetik menyukai proyek terapan lelucon pendek dan lucu dapat membantu para siswa yang memiliki gaya belajar kinestetik. Mereka juga suka belajar melalui gerakan dengan setiap fakta.

Menurut Meier (2005) mengatakan bahwa siswa yang memiliki gaya belajar auditori lebih suka belajar dari suara, dialog, membaca keras, menceritakan kepada orang lain apa yang baru saja mereka alami, dengar, pelajari, berbicara kepada diri sendiri, dari mengingat bunyi dan irama, mendengar kaset, dan mengulang suara dalam hati. Gaya belajar auditori merupakan cara belajar standar bagi semua masyarakat sejak awal sejarah.

Siswa yang memiliki gaya belajar auditori, belajar dengan menggunakan pendengaran dan cenderung interdependen serta banyak menggunakan kecerdasan interpersonal. Siswa yang memiliki gaya belajar auditori lebih suka lingkungan yang tenang. Siswa bicara sedikit lebih lambat, dan banyak menggunakan kata-kata yang berhubungan dengan pendengaran (Gunawan, 2004).

Menurut De Porter \& Henarcki (2003) mengatakan bahwa siswa yang memiliki gaya belajar auditori lebih suka mendengarkan materi dan kadang-kadang kehilangan urutan jika mencoba mencatat materi selam persentase berlangsung. Berikut ciri-ciri siswa yang memiliki gaya belajar auditori sering berbicara pada diri sendiri pada saat bekerja, mudah terganngu oleh keributan, menggerakkan bibir dan mengucapkan tulisan di buku ketika membaca, senang membaca dengan keras dan mendengarkan, merasa kesulitan untuk menulis akan tetapi hebat dalam bercerita, berbicara dalam irama teepola, lebih suka musik daripada seni lain, lebih suka guarauan lisan.

Menurut De Porter et al (2001) mendefinisikan bahwa siswa yang memiliki gaya belajar auditori mengakses segala jenis bunyi dan kata diciptakan maupun diingat. Musik, nada, irama, dialog internal, dan suara menonjol sangat mempengaruhi. Dan ciri-ciri siswa yang memiliki gaya belajar auditori perhatiannya mudah pecah, berbicara dengan pola berirama, belajar dengan cara mendengarkan, menggerakkan bibir (bersuara saat membaca), berdialog secara internal dan eksternal. 
Berdasarkan kerangka berpikir yang telah dikemukakan di atas, hipotesis penelitian ini dapat dirumuskan sebagai berikut: (1) Siswa yang diajar dengan metode pembelajaran simulasi memperoleh hasil belajar Pendidikan Kewarganegaraan lebih tinggi dibandingkan dengan siswa yang diajar dengan metode pembelajaran ekspositori; (2) Siswa yang memiliki gaya belajar kinestetik memperoleh hasil belajar Pendidikan Kewarganegaraan yang lebih tinggi dibandingkan dengan siswa yang memiliki gaya belajar auditori; dan (3) Terdapat interaksi antara metode pembelajaran dan gaya belajar dalam mempengaruhi hasil belajar Pendidikan Kewarganegaraan siswa.

\section{METODE}

Penelitian ini dilakukan di SMK Negeri 1 Balige. Populasi penelitian ini adalah seluruh siswa kelas X SMK Negeri 1 Balige dengan jumlah kelas sebanyak 19 kelas dan jumlah siswa sebanyak 619 orang. Seluruh populasi diasumsikan memiliki karakteristik yang sama, dimana setiap kelas tidak memiliki siswa yang pernah tinggal jelas, umur rata-rata siswa tidak jauh berbeda, semua siswa tidak ada yang mengikuti tes tambahan, dan kulifikasi guru Pendidikan Kewarganegaraan relatif sama.

Teknik pengambilan sampel yang digunakan dalam penelitian adalah pengambilan sampel cluster random sampling, yaitu populasi dibagi menjadi beberapa kelompok atau klaster. Secara acak kelompok-kelompok yang diperlukan diambil dengan proses pengacakan. Setiap anggota di dalam kelompok-kelompok yang diambil merupakan sampel yang diperlukan. Dari populasi terpilih dua kelas sebagai sampel yaitu kelas 1 Teknik Kendaraan Ringan 2 dan kelas 1 Teknik Sepeda Motor dengan jumlah masing-masing kelas 40 orang. Untuk menentukan jenis perlakuan dilakukan secara undian, di mana satu kelas mendapatkan metode pembelajaran simulasi dan kelas yang lain mendapatkan metode pembelajaran ekspositori. Masing-masing kelas perlakuan terbagi dalam dua karakteristik yaitu kelompok yang menggunakan memiliki gaya belajar kinestetik dan gaya belajar auditori.

Penelitian ini menggunakan metode eksperimen semu (quasi experimental research) dengan melakukan eksperimen di dalam kelas yang sudah tersedia sebagai mana adanya, tanpa melakukan perubahan situasi kelas dan jadwal pembelajaran. Perlakuan dilaksanakan pada pembelajaran pendidikan kewarganegaraan dengan membandingkan antara metode pembelajaran simulasi dengan metode pembelajaran ekspositori dan dilaksanakan pada kelas perlakuan yang telah ditetapkan. Guru yang biasa melakukan pembelajaran pendidikan kewarganegaraan di kelas-kelas tersebut diberikan petunjuk untuk melakukan pembelajaran. Di kelas 1 Teknik Kendaraan Ringan 2 melaksanakan metode pembelajaran simulasi, sedangkan di kelas 1 Teknik Sepeda Motor. Selanjutnya pada masing-masing kelas diberikan soal tes untuk mengetahui hasil belajar siswa. Dan tes gaya belajar dilakukan sebelum perlakuan untuk mengetahui gaya belajar yang dimiliki siswa. Gaya belajar siswa dikategorikan atas gaya belajar kinestetik dan gaya belajar auditori.

Desain penelitian yang digunakan dalam penelitian ini adalah desain faktorial $2 \times 2$. Sebagai variabel bebas pertama yaitu metode pembelajaran, dengan dua taraf yaitu metode pembelajaran simulasi dan metode pembelajaran ekspositori. Variabel moderator yaitu gaya belajar, dengan pengelompokkan gaya belajar kinestetik dan gaya belajar auditori. Sedangkan variabel terikatnya adalah hasil belajar Pendidikan Kewarganegaraan. Adapun desain penelitian ini dapat dilihat pada Tabel 1.

Tabel 1. Desain Penelitian Faktorial 2 x 2

\begin{tabular}{|l|c|c|}
\hline \multirow{2}{*}{$\begin{array}{c}\text { Gaya Belajar } \\
\text { (B) }\end{array}$} & \multicolumn{2}{|c|}{ Metode Pembelajaran (A) } \\
\cline { 2 - 3 } & Simulasi (A1) & Ekspositori (A2) \\
\hline Kinestetik (B1) & A1B1 (20 orang) & A2B1 (20 orang) \\
\hline Auditori (B2) & A1B2 (20 orang) & A2B2 (20 orang) \\
\hline
\end{tabular}

Keterangan:

A1B1 = Rata-rata hasil belajar Pendidikan Kewarganegaraan siswa yang memiliki gaya belajar kinestetik diajarkan dengan metode pembelajaran simulasi

A1B2 = Rata-rata hasil belajar Pendidikan Kewarganegaraan siswa yang memiliki gaya belajar auditori 


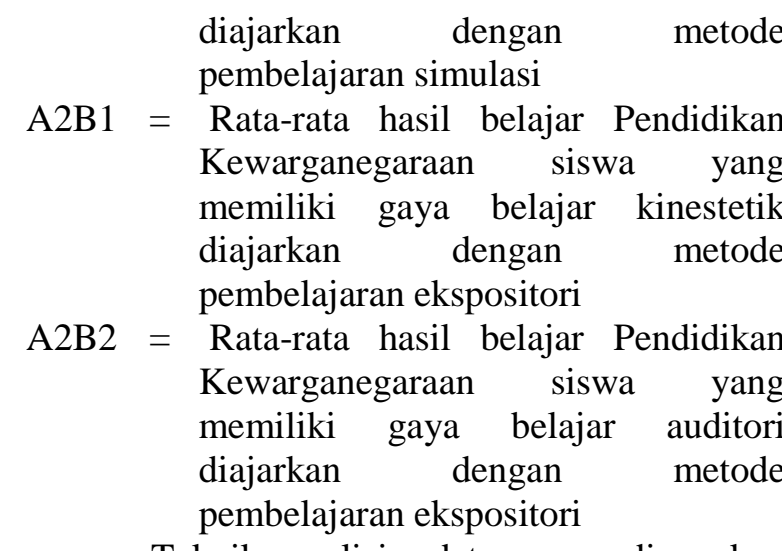

adalah teknik statistik deskriptif dan teknik statistik inferensial. Teknik statistik deskriptif digunakan untuk mendeskripsikan data, antara lain nilai rata-rata, median, modus, standar deviasi dan kecenderungan data. Teknik skatistik inferensial digunakan untuk menguji hipotesis penelitian, maka teknik analisis data yang digunakan adalah teknik analisis varians ANAVA dua jalur.

Untuk menggunakan ANAVA dua jalur perlu dipenuhi beberapa syarat yaitu: 1) data yang digunakan harus berdistribusi normal, 2) Data harus homogen. Untuk menguji normalitas data digunakan uji Lilifors dan untuk menguji homogenitas digunakan uji Bartlet dan uji Fisher. Setelah melakukan pengujian persyaratan yaitu normalitas data dan homogenitas dilanjutkan dengan pengujian ANAVA dua jalur. Jika hasil pengujian ANAVA dua jalur signifikan maka perlu dilakukan uji lanjut. Jika jumlah sampel tiap sel sama besar maka uji lanjut dilakukan dengan uji Tukey, sedangkan jika jumlah sampel tiap sel berbeda maka uji lanjut dilakukan dengan uji Scheffe.

Sedangkan rumusan hipotesis statistik dalam penelitian statistik dalam penelitian ini adalah sebagai berikut:

a) Hipotesis pertama:

$$
\begin{array}{ll}
\text { Ho } & : \mu_{A 1}=\mu_{A 2} \\
\text { Ha } & : \mu_{A 1}>\mu_{A 2}
\end{array}
$$

b) Hipotesis kedua:

$$
\begin{array}{ll}
\text { Ho } \quad: \mu_{B 1}=\mu_{B 2} \\
\text { Ha } \quad: \mu_{B 1}>\mu_{B 2} \\
\text { c) Hipotesis ketiga: } \\
\text { Ho } \quad: A \times B=0 \\
\text { Ha } \quad: A \times B \neq 0
\end{array}
$$

Keterangan :

$$
\begin{aligned}
& \mu_{A 1}=\text { Hasil belajar Pendidikan } \\
& \text { Kewarganegaraan siswa yang diajarkan } \\
& \text { dengan Metode Pembelajaran Simulasi. } \\
& \mu_{A 2}=\text { Hasil belajar Pendidikan } \\
& \text { Kewarganegaraan siswa yang diajarkan } \\
& \text { dengan Metode Pembelajaran } \\
& \text { Ekspositori. } \\
& \mu_{B 1}=\text { Hasil belajar Pendidikan } \\
& \text { Kewarganegaraan siswa yang memiliki } \\
& \text { Gaya Belajar Kinestetik. }
\end{aligned}
$$

$\mu_{B 2}=$ Hasil belajar Pendidikan Kewarganegaraan siswa yang memiliki Gaya Belajar Auditorial

$\mathrm{AxB}=$ Interaksi antara metode pembelajaran dengan gaya belajar.

\section{HASIL DAN PEMBAHASAN \\ Hasil}

Data yang telah dikumpulkan melalui penelitian ditabulasi sesuai dengan keperluan analisis data yang tercantum dalam rancangan penelitian yang bertujuan untuk menunjukkan gambaran umum mengenai penyebaran atau distribusi data. Penelitian ini adalah penelitian kuasi eksperimen dengan rancangan analisis faktorial $2 \times 2$. Berdasarkan rancangan analisis, maka data yang akan disajikan adalah (1) hasil belajar Pendidikan Kewarganegaraan siswa yang diajar dengan metode pembelajaran simulasi, (2) hasil belajar Pendidikan Kewarganegaraan siswa yang diajar dengan metode pembelajaran ekspositori, (3) hasil belajar Pendidikan Kewarganegaraan siswa yang memiliki gaya belajar kinestetik, (4) hasil belajar Pendidikan Kewarganegaraan siswa yang memiliki gaya belajar auditori, (5) hasil belajar Pendidikan Kewarganegaraan siswa yang memiliki gaya belajar kinestetik yang diajar dengan metode pembelajaran simulasi, (6) hasil belajar Pendidikan Kewarganegaraan siswa yang memiliki gaya belajar kinestetik yang diajar dengan metode pembelajaran ekspositori, (7) hasil belajar Pendidikan Kewarganegaraan siswa yang memiliki gaya belajar auditori yang diajar dengan metode pembelajaran simulasi, dan (8) hasil belajar Pendidikan Kewarganegaraan siswa yang memiliki gaya belajar auditori yang diajar dengan metode pembelajaran ekspositori. 
Tabel 2. Ringkasan Data Hasil Penelitian untuk ANAVA Faktorial $2 \times 2$

\begin{tabular}{|c|c|c|c|c|}
\hline \multirow{2}{*}{\multicolumn{2}{|c|}{ Variabel }} & \multicolumn{2}{|c|}{ Metode Pembelajaran (A) } & \multirow{3}{*}{$\begin{array}{l}\text { Total } \\
n=40 \\
\bar{X}=46,80 \\
s=4,35\end{array}$} \\
\hline & & \multirow{2}{*}{\begin{tabular}{l}
\multicolumn{1}{c}{ Simulasi $\left(A_{1}\right)$} \\
$n=20$ \\
$\bar{X}=50,10$ \\
$s=2,31$
\end{tabular}} & \multirow{2}{*}{$\begin{array}{l}\text { Ekspositori }\left(A_{2}\right) \\
n=20 \\
\bar{X}=43,50 \\
s=3,24\end{array}$} & \\
\hline \multirow[b]{2}{*}{$\begin{array}{l}\text { Gaya } \\
\text { Belajar } \\
\text { ( B) }\end{array}$} & $\begin{array}{l}\text { Kinestetik } \\
\quad\left(B_{1}\right)\end{array}$ & & & \\
\hline & $\begin{array}{c}\text { Auditori } \\
\left(B_{2}\right)\end{array}$ & $\begin{array}{l}n=20 \\
\bar{X}=43,35 \\
s=3,56\end{array}$ & $\begin{array}{l}n=20 \\
\bar{X}=46,15 \\
s=3,20\end{array}$ & $\begin{array}{l}n=40 \\
\bar{X}=44,75 \\
s=3,63\end{array}$ \\
\hline \multicolumn{2}{|c|}{ Total } & $\begin{array}{l}n=40 \\
\bar{X}=46,73 \\
s=4,52\end{array}$ & $\begin{array}{l}n=40 \\
\bar{X}=44,83 \\
s=3,45\end{array}$ & $\begin{array}{l}n=80 \\
\bar{X}=45,78 \\
s=4,11\end{array}$ \\
\hline
\end{tabular}

Setelah pengujian persyaratan analisis dilakukan, diperoleh hasil bahwa semua data kelompok subjek berdistribusi normal dan mempunyai varians yang homogen, dengan demikian persyaratan sehubungan dengan teknik analisis varians dua jalur telah terpenuhi. Selanjutnya diolah dengan teknik analisis varians faktorial $2 \times 2$, dan diperoleh hasil perhitungan yang divisualisasikan pada Tabel 3 .

Tabel 3.Ringkasan Hasil Perhitungan ANAVA Faktorial 2 x 2

\begin{tabular}{|l|c|c|c|c|c|}
\hline $\begin{array}{c}\text { Sumber } \\
\text { Variasi }\end{array}$ & dk & JK & RJK & $F_{\text {hitung }}$ & $\begin{array}{c}F_{\text {tabel }} \\
(\alpha=0,05)\end{array}$ \\
\hline Antar Kolom (A) & 1 & 72,2 & 72,2 & 7,47 & 3,968 \\
Antar Baris (B) & 1 & 84,05 & 84,05 & 8,69 & 3,968 \\
Interaksi (A x B) & 1 & 441,8 & 441,8 & 45,69 & 3,968 \\
Galat & 76 & 735 & 9,67 & & \\
\hline \multicolumn{1}{|c|}{ Total } & 79 & & & & \\
\hline
\end{tabular}

Hasil Belajar Pendidikan Kewarganegaraan Siswa yang Diajar dengan Metode Pembelajaran Simulasi Lebih Tinggi daripada Ekspositori

Rumusan hipotesis statistik yang diuji adalah sebagai berikut.

$H_{0}: \mu_{A 1}=\mu_{A 2}$

$H_{a}: \mu_{A 1}>\mu_{A 2}$

Dari hasil perhitungan diperoleh bahwa rata-rata hitung hasil belajar Pendidikan Kewarganegaraan siswa yang diajar dengan metode pembelajaran simulasi 46,73 , dan ratarata hitung hasil belajar Pendidikan Kewarganegaraan siswa yang diajar dengan metode pembelajaran ekspositori 44,83.

Berdasarkan hasil perhitungan analisis varians pada Tabel 22, diperoleh bahwa hasil perhitungan data model pembelajaran nilai
$F_{\text {hitung }}=7,47$ dan nilai kritik $F_{\text {tabel }}$ untuk taraf signifikan $\alpha=0,05$ dengan derajat kebebasan pembilang $=1$ dan derajat kebebasan penyebut $=$ 76 adalah 3,968. Hasil ini menunjukkan bahwa $F_{\text {hitung }}>F_{\text {tabel }}$, sehingga $H_{0}$ ditolak, dengan demikian dapat dinyatakan bahwa hasil belajar Pendidikan Kewarganegaraan siswa yang diajar dengan metode pembelajaran simulasi lebih tinggi daripada hasil belajar Pendidikan Kewarganegaraan siswa yang diajar dengan metode pembelajaran ekspositori, dan hipotesis penelitian teruji secara empirik.

Hasil Belajar Pendidikan Kewarganegaraan Siswa yang Memiliki Gaya Belajar Kinestetik Lebih Tinggi daripada Auditori

Rumusan hipotesis statistik yang diuji adalah sebagai berikut. 


$$
\begin{aligned}
& H_{0}: \mu_{B 1}=\mu_{B 2} \\
& H_{a}: \mu_{B 1}>\mu_{B 2}
\end{aligned}
$$

Dari hasil perhitungan diperoleh bahwa rata-rata hitung hasil belajar Pendidikan Kewarganegaraan siswa yang memiliki gaya belajar kinestetik 46,80, dan rata-rata hitung hasil belajar Pendidikan Kewarganegaraan siswa yang memiliki gaya belajar auditori 44,75.

Berdasarkan hasil perhitungan analisis varians pada Tabel 22, diperoleh hasil perhitungan data gaya belajar yaitu $F_{\text {hitung }}=8,69$ dan nilai kritik $F_{\text {tabel }}$ untuk taraf signifikan $\alpha=0,05$ dengan $\mathrm{df}=(1,76)$ adalah 3,968 . Hasil ini menunjukkan bahwa $\quad F_{\text {hitung }}>F_{\text {tabel }}$, sehingga $H_{0}$ ditolak, dengan demikian dapat dinyatakan bahwa hasil belajar Pendidikan Kewarganegaraan siswa yang memiliki gaya belajar kinestetik lebih tinggi daripada hasil belajar Pendidikan Kewarganegaraan siswa yang memiliki gaya belajar auditori, dan hipotesis penelitian yang diajukan teruji secara empirik.

Interaksi Antara Metode Pembelajaran dan

\section{Gaya Belajar Terhadap Hasil Belajar Pendidikan Kewarganegaraan}

Rumusan hipotesis statistik yang akan diuji adalah sebagai berikut.

$$
H_{0}: A><B=0
$$

$$
H_{a}: A><B \neq 0
$$

Perolehan rata-rata hitung hasil belajar PendidikanKewarganegaraansiswa yang memiliki gaya belajar kinestetik siswa dan diajar dengan metode pembelajaran simulasi 50,10, dan siswa yang diajar dengan metode pembelajaran ekspositori 43,50. Rata-rata hitung hasil belajar Pendidikan Kewarganegaraan siswa yang memiliki gaya belajar auditori dan diajar dengan metode pembelajaran simulasi 43,35 , dan siswa yang diajar dengan metode pembelajaran ekspositori 46,15.

Berdasarkan hasil perhitungan pada Tabel 22, diperoleh bahwa $F_{\text {hitung }}=45,69$ dan nilai kritik $F_{\text {tabel }}$ untuk taraf signifikan $\alpha=0,05$ dengan $\mathrm{dk}=(1,76)$ adalah 3,968 . Hasil ini menunjukkan bahwa $F_{\text {hitung }}>F_{\text {tabel }}$, maka $H_{0}$ ditolak, sehingga dapat dinyatakan bahwa terdapat interaksi antara metode pembelajaran dan gaya belajar terhadap hasil belajar Pendidikan Kewarganegaraan, dan hipotesis yang diajukan teruji secara empirik.

Untuk melihat model analisis varians yang menunjukkan adanya interaksi antara metode pembelajaran dan gaya belajar terhadap hasil belajar Pendidikan Kewarganegaraan divisualisasikan secara grafis pada Gambar 9 sebagai berikut.

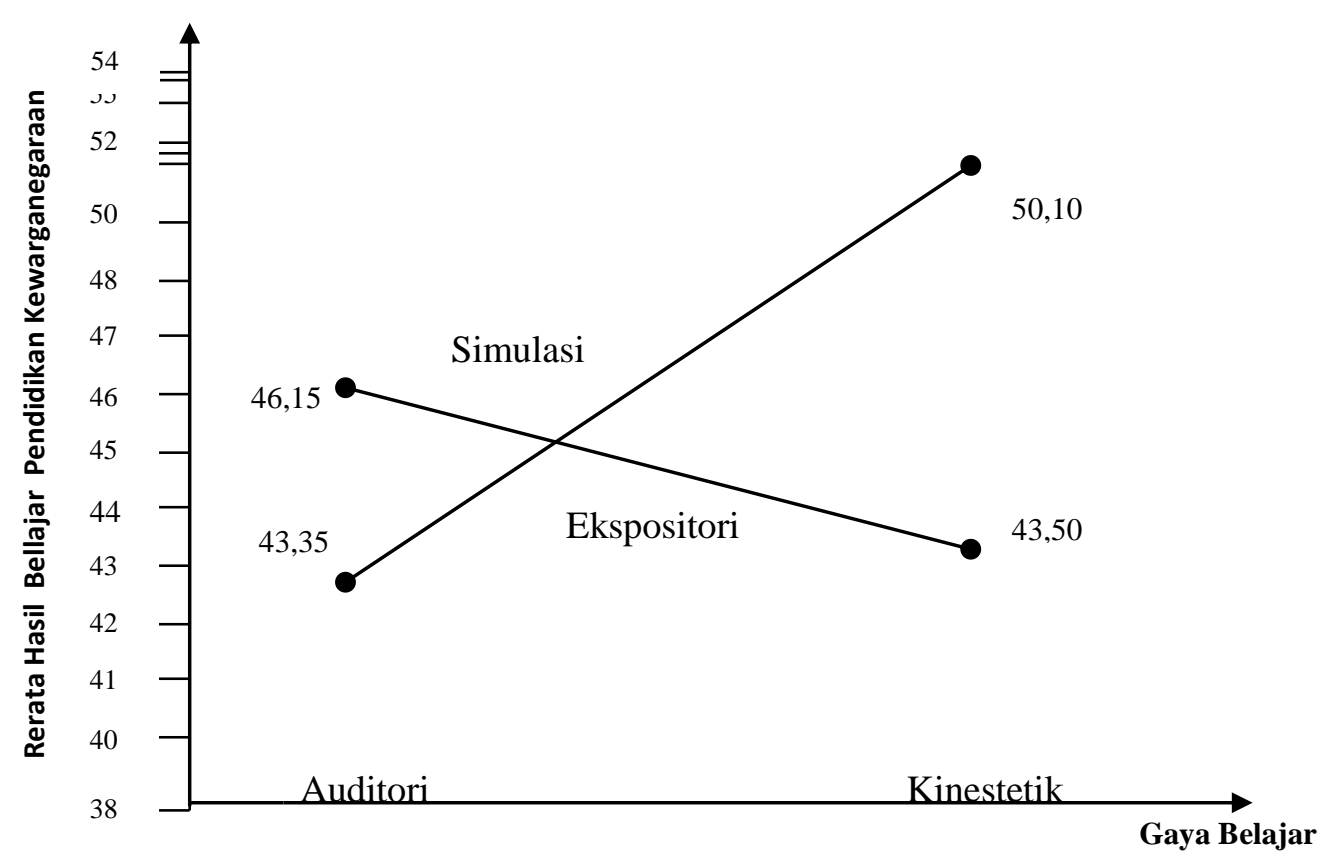

Gambar 1. Interaksi antara Metode Pembelajaran dan Gaya Belajar 'l'erhadap Hasil Belajar Pendidikan Kewarganegaraan 
Untuk mengetahui interaksi antara metode pembelajaran dengan gaya belajar dalam mempengaruhi hasil belajar Pendidikan Kewarganegaraan, dilakukan uji lanjut dengan menggunakan Uji Tukey. Ringkasan hasil perhitungan uji Tukey divisualisasikan pada Tabel 4.

Tabel 4. Ringkasan Hasil Perhitungan Uji Tukey

\begin{tabular}{|c|c|c|c|c|c|}
\hline No & $\begin{array}{l}\text { Kelompok } \\
\text { Subjek }\end{array}$ & Hipotesis Statistik & $Q_{\text {hitung }}$ & $Q_{\text {tabel }}$ & Kriteria \\
\hline \multirow[t]{2}{*}{1.} & \multirow[t]{2}{*}{$A_{1} B_{1}-A_{2} B_{1}$} & $H_{0}: \mu_{A 1 B 1}=\mu_{A 2 B 1}$ & \multirow[b]{2}{*}{4,75} & \multirow[b]{2}{*}{3,96} & \multirow{2}{*}{ Signifikan } \\
\hline & & $H_{a}: \mu_{A 1 B 1}>\mu_{A 2 B 1}$ & & & \\
\hline \multirow[t]{2}{*}{2.} & \multirow[t]{2}{*}{$A_{2} B_{2}-A_{1} B_{2}$} & $H_{0}: \mu_{A 2 B 2}=\mu_{A 1 B 2}$ & \multirow{2}{*}{4,03} & \multirow{2}{*}{3,96} & \multirow{2}{*}{ Signifikan } \\
\hline & & $H_{a}: \mu_{A 2 B 2}>\mu_{A 1 B 2}$ & & & \\
\hline \multirow[t]{2}{*}{3.} & \multirow[t]{2}{*}{$A_{1} B_{1}-A_{1} B_{2}$} & $H_{0}: \mu_{A 1 B 1}=\mu_{A 1 B 2}$ & \multirow{2}{*}{9,71} & \multirow{2}{*}{3,96} & \multirow{2}{*}{ Signifikan } \\
\hline & & $H_{a}: \mu_{A 1 B 1}>\mu_{A 1 B 2}$ & & & \\
\hline \multirow[t]{2}{*}{4.} & \multirow[t]{2}{*}{$A_{2} B_{2}-A_{2} B_{1}$} & $H_{0}: \mu_{A 2 B 2}=\mu_{A 2 B 1}$ & \multirow{2}{*}{3,81} & \multirow{2}{*}{3,96} & \multirow{2}{*}{$\begin{array}{c}\text { Tidak } \\
\text { Signifikan }\end{array}$} \\
\hline & & $H_{a}: \mu_{A 2 B 2}>\mu_{A 2 B 1}$ & & & \\
\hline \multirow[t]{2}{*}{5.} & \multirow[t]{2}{*}{$A_{1} B_{1}-A_{2} B_{2}$} & $H_{0}: \mu_{A 1 B 1}=\mu_{A 2 B 2}$ & \multirow{2}{*}{5,68} & \multirow{2}{*}{3,96} & \multirow{2}{*}{ Signifikan } \\
\hline & & $H_{a}: \mu_{A 1 B 1}>\mu_{A 2 B 2}$ & & & \\
\hline \multirow[t]{2}{*}{6.} & \multirow[t]{2}{*}{$A_{2} B_{1}-A_{1} B_{2}$} & $H_{0}: \mu_{A 2 B 1}=\mu_{A 1 B 2}$ & \multirow{2}{*}{0,22} & \multirow{2}{*}{3,96} & \multirow{2}{*}{$\begin{array}{c}\text { Tidak } \\
\text { Signifikan }\end{array}$} \\
\hline & & $H_{a}: \mu_{A 2 B 1}>\mu_{A 1 B 2}$ & & & \\
\hline
\end{tabular}

\section{Pembahasan}

Keunggulan dari metode pembelajaran simulasi diuraikan pada kerangka berpikir terbukti secara empiris dilapangan, sehingga hasil ini menguatkan bahwa dengan metode pembelajaran simulasi hasil belajar pendidikan kewarganegaraan siswa lebih baik. Keunggulan yang lain dari metode pembelajaran simulasi yang ditemukan dilapangan dari nilai rata-rata hasil belajar siswa di kelas X SMK Negeri 1 Balige lebih tertarik belajar dengan menggunakan metode pembelajaran simulasi dibandingkan dengan belajar teori atau konsep saja, sehingga pada umumnya siswa lebih menyenangi bila proses pembelajaran langsung dilakukan pemeranan yang akan dipelajari melalui simulasi dibandingkan dengan konsep yang terkait dengan materi pelajaran yang akan disampaikan guru. Berdasarkan kenyataan metode pembelajaran simulasi ekspositori kurang menghasilkan hasil yang maksimal bagi siswa karena kurang tertarik untuk siswa untuk mendengarkan konsep akibatnya siswa kurang dapat memperoleh materi. Selanjutnya dengan metode pembelajaran ekspositori siswa kurang berkoorsinasi dan kurang berkomunikasi dengan teman-temannya karena masing-masing mendengarkan materi yang disampaikan oleh guru. Sedangkan dengan metode pembelajaran simulasi siswa lebih bebas untuk berkoordinasi dan mengkomunikasikan temuan yang diperoleh dengan teman pada saat melakukan kegiatan belajar. Komunikasi anatara teman dan guru akan memberikan solusi yang cepat bagi siswa untuk memperoleh pelajaran tersebut.

Berdasarkan temuan yang dikemukankan secara umum peerbedaan antara metode pembelajaran simulasi dengan metode pembelajaran ekspositori terletak dalam aspek antara lain, bahwa metode pembelajaran ekspositori menunjukkan ciri suatu proses pembelajaran dimana guru sebagai penyampai materi pelajaran kepada siswa, sedangkan metode pembelajaran simulasi di dalam proses pembelajaran siswa akan menemukan sendiri lebih banyak informasi melalui pengalaman yang terjadi pada dirinya atau orang lain di lingkungan sekitarnya. Pembelajaran dengan menggunakan metode pembelajaran ekspositori dan metode pembelajaran simulasi dipandang dapat mengembangkan metode pembelajaran yang mampu membina siswa. Hanya saja dengan metode pembelajaran ekspositori lebih berpusat pasa guru yang menyampaikan materi pelajaran sedangkan dengan metode pembelajaran simulasi akan memberikan kesempatan bagi siswa untuk memerankan materi yang terkait dalam pelajaran untuk meningkatkan pengetahuan serta 
kemampuan mereka dalam menyelesaikan permasalahan yang terjadi pada kehidupan sehari-hari di lingkungan masyarakat.

Hal ini didukung dengan pernyataan Joyce B (2009) Metode Simulasi, melalui aktivitas nyata dan diskusi diawal permainan, menuntun pada hasil-hasil akademik. Seperti konsep dan skill, kerjasama dan persaingan; pemikiran kritis dan pembuatan keputusan; pengetahui sistem politik sosial, dan ekonomi efektivitas; kesadaran terhadap masing-masing peran; dan menerima konsekuensi dari tindakan yang dilakukan. Demikian juga, Wahab (2007) yang menyatakan bahwa pada metode simulasi amat memungkinkan bagi peningkatan perhatian serta minat siswa karena sifatnya yang menekankan pada bermain sambil belajar.

Seperti diketahui bahwa gaya belajar siswa sangat berpengaruh terhadap hasil belajar. Gaya belajar siswa yang terjadi dapat menemukan pengetahuan yang baru. Dengan demikian siswa yang memiliki gaya belajar akan memahami konsep lebih baik dan siswa akan lebih mudah mempelajari materi. Dengan adanya pengetahuan siswa akan dapat menyusun kesimpulan dengan lebih mudah tentang apa yang dipelajarai. Setelah itu, siswa dapat mengaplikasikan konsep itu dalam pemecahan masalah yang dihadapi baik dalam kegiatan di lapangan, maupun dalam kehidupan masyarakat secara langsung. Kondisi ini teruji secara empiris dengan temuan penelitian yang membuktikan bahwa terdapat perbedaan hasil belajar siswa yang signifikan antara kelompok siswa yang memiliki gaya belajar kinestetik dengan kelompok siswa yang memiliki gaya belajar auditori. Hasil temuan membuktikan bahwa ratarata skor hasil belajar siswa yang memiliki gaya belajar kinestetik adalah 46,80 lebih tinggi dari rata-rata skor hasil belaja siswa yang memiliki gaya belajar auditori adalah 44,75. Dapat dipahami bahwa siswa yang memiliki gaya belajar kinestetik akan lebih mudah mentrsnsfer pengetahuan dan termotivasi untuk memcahkan masalah yang dihadapi. Sebaliknya siswa yang memiliki gaya belajar auditori kurang bergairah dalam belajar, kurang berani dalam mengajukan pertanyaan dan kurang berani memberi komentar terhadap materi pelajaran serta kurang aktif dalam proses pembelajaran.

Secara keseluruhan hasil belajar siswa yang memiliki gaya belajar auditori pada metode pembelajaran simulasi dan metode pembelajaran ekspositori bila dibandingkan perbedaan, ternyata hasilnya sama. Hal ini terbukti dari hasil temuan yang menguatkan bahwa hasil belajar siswa yang memiliki gaya belajar auditori pada metode pembelajaran simulasi berbeda dengan hasil belajar pendidikan kewarganegaraan siswa yang memiliki gaya belajar auditori pada metode pembelajaran ekspositori. Berdasarkan hasil penelitian yang diperoleh memberikan gambaran bahwa dalam metode pembelajaran simulasi dan metode pembelajaran ekspositori sangat perlu untuk memperhatikan gaya belajar yang dimiliki oleh siswa.

Hal ini didukung oleh Gunawan (2004) yang menyatakan bahwa orang kinestetik sangat peka terhadap peasaan atau emosi dan pada sensasi sentuhan dan gerakan. Jika kinestetik diajar dengan metode simulasi berarti telah membangkitkan "emosi" dan gerakan bagi mereka dalam mengolah informasi. Demikian juga De Porte et al (2001) yang mengemukakan bahwa mereka suka belajar melalui gerak dan paling baik menghafal infomasi dengan mengasosiasikan gerakan dengan setiap fakta telah sesuai dengan temuan peneliti.

Dari hasil perhitungan statistik deskriptif, terbukti bahwa terdapat interaksi antara metode pembelajaran dengan gaya belajar dalam mempengaruhi hasil belajar siswa. Hal ini memberikan indikasi bahwa kelompok siswa yang memiliki gaya belajar kinestetik berbeda dengan kelompok siswa yang memiliki gaya belajar auditori, artinya bahwa salah satu dari kedua kelompok akan memperoleh hasil belajar siswa yang lebih baik bila diajar dengan metode pembelajaran simulasi dan yang lainnya akan tidak terdapat perbedaan bila diajar dengan metode pembalajaran ekspositori. Berdasarkan dari hasil temuan penelitian bahwa kelompok siswa yang memiliki gaya belajar kinestetik memperoleh rata-rata skor hasil belajar siswa lebih tinggi bila diajar dengan menggunakan metode pembelajaran simulasi. Kelompok siswa yang memiliki gaya belajar auditori memperoleh rata-rata skor hasil belajar pendidikan kewarganegaraan lebih tinggi bila diajar dengan menggunakan metode pembelajaran ekspositori. Hal ini dapat dijelaskan bahwa siswa yang memiliki gaya belajar kinestetik akan lebih menunjukkan aktifitas yang lebih aktif dalam pembelajaran, lebih senang dengan melakukan kegiatan pemeranan dan tertarik dengan penemuan hal yang baru sehingga karakteristik ini akan lebih sesuai dengan metode pembelajaran simulasi. Sebaliknya siswa yang memiliki gaya belajar auditori mereka ragu-ragu dalam mengungkapkan pendapatnya, cenderung 
kurang aktif hal ini disebabkan akibat kurannya pengetahuan yang dimiliki siswa sehingga mereka lebih senang untuk mendengarkan guru dalam menyampaikan materi pembelajaran sehingga kondisi ini akan membantu untuk meningkatkan hasil belajar siswa.

Berdasarkan temuan ini memberikan gambaran bahwa penerapan metode pembelajaran terhadap hasil belajar perlu memperhatikan gaya belajar yang dimiliki oleh siswa untuk membantu siswa dalam mencapai hasil belajar yang baik. Penemuan penelitian yang lebih unik menunjukkan bahwa hasil belajar siswa kelompok yang memiliki gaya belajar kinestetik yang diajar dengan menggunakan metode pembelajaran simulasi terdapat perbedaan yang sangat signifiakn dengan kelompok siswa yang diajar dengan metode pembelajaran ekspositori. Hal ini memberikan indikasi bahwa metode pembelajaran simulasi memang memberikan pengaruh yang dominan dalam meningkatkan hasil belajar siswa, sedangkan dua kelompok yang lainnya tidak menunjukkan perbedaan ratarata skor dari hasil belajar siswa yang signifikan. Artinya bahwa interaksi antara metode pembelajaran denagan gaya belajar terjadi pada rata-rata skor hasil belajar siswa pada gaya belajar auditori sehingga tercermin bahwa ratarata skor hasil belajar siswa yang lebih tinggi didominasi pada kelompok metode pembelajaran simulasi untuk siswa yang memiliki gaya belajar kinestetik.

Hasil penelitian ini juga memberikan gambaran bahwa hasil belajar siswa yang diajar dengan metode pembelajaran simulasi menunjukkan kecenderungan untuk memperoleh hasil belajar yang lebih baik bagi siswa yang memiliki gaya belajar kinestetik. Sedangkan siswa yang diajar dengan metode pembelajaran ekspositori menunjukkan perubahan penongkatan hasil belajar siswa yang signifikan antara kelompok siswa yang memiliki gaya belajar kinestetik dengan siswa yang memiliki gaya belajar auditori. Artinya ditemukan bahwa bagi siswa yang memiliki gaya belajar auditori hasil belajar siswa lebih baik bila dibandingkan dengan kelompok siswa yang memiliki gaya belajar kinestetik.

\section{PENUTUP}

Berdasarkan hasil pengujian hipotesis, maka dalam penelitian ini dapat disimpulkan sebagai berikut :
1. Hasil belajar Pendidikan Kewarganegaraan siswa yang diajar dengan metode pembelajaran simulasi lebih tinggi daripada hasil belajar Pendidikan Kewarganegaraan siswa yang diajar dengan metode pembelajaran ekspositori.

2. Hasil belajar Pendidikan Kewarganegaraan siswa yang memiliki gaya belajar kinestetik tinggi lebih tinggi daripada siswa yang memiliki gaya belajar auditori.

3. Ada interaksi antara metode pembelajaran dan gaya belajar terhadap hasil belajarPendidikan Kewarganegaraan.

Berdasarkan nilai rerata hasil belajar Pendidikan Kewarganegaraan yang diperoleh menunjukkan bahwa siswa yang memiliki gaya belajar kinestetik dan diajar dengan metode pembelajaran simulasi memperoleh hasil lebih tinggi daripada yang diajar dengan metode pembelajaran ekspositori. Sedangkan siswa yang memiliki gaya belajar auditori memperoleh hasil belajar Pendidikan Kewarganegaraan lebih tinggi jika diajar dengan metode pembelajaran ekspositori daripada diajar dengan model pembelajaran simulasi.

\section{DAFTAR PUSTAKA}

Aumurrahman. 2009. Belajar dan Pembelajaran. Bandung: Alfabeta.

DeCecoo and and Vrowford. 1983. The psichology of Learning and Instruction. New Delhi: Prentice- Holt of Indian.

De Porter, B \& Hernacki, M. 2003. Quantum Teaching. Bandung: Kaifa.

De Porter, B, et. al, 2001. Quantum Teaching. Bandung: Kaifa.

Dick \& Carey. 2001. The Systematic Design of Instruction. New York: Wesley Educational.

Djamarah dan Zain. 2006. Strategi Belajar Mengajar. Jakarta: Rineka Cipta.

Gagne, R.M dan Briggs, L. J. 1979. Principles of Instruction Design. New York: Holt, Rinehalt and Winston.

Gunawan, Adi. W. 2004. Genius Learning Strategy. Jakarta: Gramedia.

Hamalik. 2001. Perencanaan Pengajaran Berdasarkan Pendekatan Sistim. Jakarta: Bumi Aksara.

Hutajulu. 2007. Pengaruh Metode Pembelajaran dan Gaya Belajarterhadap Hasil Belajar terhadap Hasil Belajar Matematika Sekolah Dasar di Kecamatan Pangaribuan. Tesis. Medan: Program Pascasarjana Universitas Negeri Medan. 
Joyce, B. dan Weil, M. 2009. Model of Teaching Model-model Pengajaran. Yogyakarta: Pustaka Pelajar.

Meier, D. 2005. The Accelerated Learning. Bandung: Mizan Pustaka.

Melvita. 2009. Pengaruh Strategi Pembelajaran dan Gaya Belajar terhadap Hasil Belajar Bahasa Inggris di SMA Negeri 4 Banda Aceh. Tesis. Medan: Program Pascasarjana Universitas Negeri Medan.

Miarso, Y. 2004. Menyemai Benih Teknologi Pendidikan. Jakarta: Prenada Media.

Nasution, S. 2005. Berbagai Pendekatan Dalam Proses Belajar Mengajar. Jakarta: Bumi Aksara.

Nuraina. 2007. Pengaruh Strategi Pembelajaran dan Gaya Belajar terhadap Hasil Belajar Matematika SMA Negeri 1 Rantau Utara. Tesis. Medan: Program Pascasarjana Universitas Negeri Medan.

Reigeluth, M. Charles. 1983. InstructionalDesign Theories And Models: An Overview of Their Current Status. Hillsdale, New Jersey London: Lawrence Erlbaum Associates.

Rusman, 2009. Manajemen Kurikulum. Jakarta: PT. Raja Grafindo Persada.

Sanjaya, W. 2007. Strategi Pembelajaran Berorientasi Standar Proses Pendidikan. Jakarta: Kencana Prenada Media Group.

Seel BB, and Richey. 1994. Instruction Technology: The defenition and domain of Field. Washington, DC: AECT.
Slameto. 2003. Belajar dan Faktor-faktor yang Mempengaruhinya. Jakarta: PT. Rineka cipta.

Snelbecker, G. E. 1984. Learning Theory, Instructional Theory; and Psycho Educational Design. New York: Mc. Graw-Hill Book.

Soemantri. 2001. Mengganggas Pembaharuan Pendidikan IPS. Bandung: PT. Remaja Rosdakarya.

Suparno, Paul. 2002. Filsafat Konstrukivisme dalam Pendidikan. Yogyakarta: Kanisius.

Surparman, Atwi. 1997. Desian Instruksional. Jakarta: Gramedia Pustaka Utama.

Suryabrata. 2004. Psikologi Pendidikan.Yogyakarta: PT. Raja Grafindo.

Suryosubroto. 2009. Proses Belajar Mengajar di Sekolah. Jakarta: PT. Rineka Cipta.

Syah. D.Supardi, dan Hasibuan. A.A. 2009. Pengantar Statistik Pendidikan. Jakarta: Gaung Persada Press.

Syah, Muhibbin. 2003. Psikologi Belajar. Jakarta: Raja Grafindo Persada.

Syukur.2008. Teknologi Pendidikan. Semarang: Rasail Media Group.

Wahab. Abdul. Azis 2008. Metode dan Modelmodel Mengajar Ilmu Pengetahuan Sosial. Bandung: Alfabeta.

Winkel, W.S. 2009. Psikologi Pengajaran. Jakarta: Gramedia. 